\title{
E2F1 induces apoptosis and sensitizes human lung adenocarcinoma cells to death-receptor-mediated apoptosis through specific downregulation of c-FLIP short
}

\author{
C Salon ${ }^{1}$, B Eymin ${ }^{\star, 1}, 0$ Micheau ${ }^{2}$, L Chaperot ${ }^{3}$, J Plumas ${ }^{3}$, \\ C Brambilla ${ }^{1}$, E Brambilla ${ }^{1}$ and S Gazzeri ${ }^{1}$ \\ 1 Groupe de Recherche sur le Cancer du Poumon, INSERM U578, Institut Albert \\ Bonniot, La Tronche Cedex, France \\ 2 INSERM U517, Faculté de Médecine et Pharmacie, Bd Jeanne d'Arc, Dijon, \\ France \\ 3 Etablissement Français du Sang, EFS Rhône-Alpes, CHU Michallon, La \\ Tronche Cedex, France \\ * Corresponding author: B Eymin, Groupe de Recherche sur le Cancer du \\ Poumon, INSERM U578, Institut Albert Bonniot, 38706 La Tronche Cedex, \\ France; Tel: + 33 476549553; Fax: + 33 476549413; \\ E-mail: Beatrice.Eymin@ujf-grenoble.fr
}

Received 10.2.05; revised 27.5.05; accepted 30.6.05; published online 29.7.05 Edited by J Tschopp

\begin{abstract}
E2F1 is a transcription factor that plays a well-documented role during $S$ phase progression and apoptosis. We had previously postulated that the low level of E2F1 in primary lung adenocarcinoma contributes to their carcinogenesis. Here, we show that E2F1 triggers apoptosis in various lung adenocarcinoma cell lines by a mechanism involving the specific downregulation of the cellular FLICE-inhibitory protein short, leading to caspase-8 activation at the deathinducing signaling complex. Importantly, we also provide evidence that E2F1 sensitizes tumor as well as primary cells to apoptosis mediated by FAS ligand or tumor necrosis factor-related apoptosis-inducing ligand, and enhances the cytotoxic effect of $T$ lymphocytes against tumor cells. Finally, we describe the specific overexpression of $c$-FLIP in human lung adenocarcinomas with low level of E2F1. Overall, our data identify E2F1 as a critical determinant of the cellular response to death-receptor-mediated apoptosis, and suggest that its downregulation contributes to the immune escape of lung adenocarcinoma tumor cells.

Cell Death and Differentiation (2006) 13, 260-272.

doi:10.1038/sj.cdd.4401739; published online 29 July 2005
\end{abstract}

Keywords: apoptosis; death receptor; E2F1; c-FLIP; lung tumors

Abbreviations: APAF-1, apoptosis protease-activating factor 1; FADD, Fas-associated death domain-containing protein; FasL, Fas ligand; FLICE, Fas-associated death domain-like interleukin $1 \beta$-converting enzyme; DISC, death-inducing signaling complex; c-FLIP, FLICE inhibitory protein; RB, retinoblastoma; TRAIL, tumor necrosis factor-related apoptosis-inducing ligand

\section{Introduction}

The E2F transcription factors family plays a major role in regulating a diverse array of cellular functions including proliferation, differentiation and apoptosis. ${ }^{1}$ So far, seven distinct E2F proteins (E2F1-7) with different affinities for the pRB pocket family have been identified. ${ }^{2,3}$ The interaction of E2Fs with the pRB members tightly controls their transcriptional as well as their repressive functions on target genes mostly involved in $\mathrm{G}_{1}$ to $\mathrm{S}$ phase transition. ${ }^{4}$ If individual E2F proteins demonstrate overlapping functions in the control of cell cycle progression, they also display distinct specificities. ${ }^{5}$ Actually, only E2F1, E2F2 and E2F3 are able to induce apoptosis in fibroblasts. ${ }^{5-9}$ In addition, E2F1-deficient mice exhibit a defect in thymocyte apoptosis as well as in negative selection demonstrating the role of E2F1 during the physiological apoptotic processes. ${ }^{10,11}$ Importantly, as these mice also develop tumors, ${ }^{10,12}$ it has been proposed that E2F1mediated apoptosis could contribute to its tumor suppressive function. E2F1-induced apoptosis occurs via both p53dependent and -independent pathways, and involves the transcriptional activation of numerous proapoptotic E2F1target genes including $p 14^{A R F} / p 19^{A R F}$, $p 73$, apaf1 and caspases. ${ }^{8,13,14}$ Moreover, alternative models suggest that E2F1 also inhibits antiapoptotic signals such as NF- $\kappa \mathrm{B}$, or sensitizes cells to proapoptotic stimuli (for a review, see Ginsberg ${ }^{15}$ ). Recently, a link between E2F1 and the extrinsic apoptotic pathway also called death receptor-related apoptosis has been established in murine primary $\mathrm{T}$ cells ${ }^{16}$ and postmitotic neurons. ${ }^{17}$

FAS (also CD95, APO-1) is a 45-kDa cell surface protein that belongs to the tumor necrosis factor (TNF)/nerve growth factor (NGF) receptors family. ${ }^{18}$ Following stimulation by its cognate ligand (FasL) or by agonistic FAS antibodies, FAS oligomerizes and recruits several death-associated molecules, including the FADD adaptator (Fas-associated death domain-containing protein, also MORT1) ${ }^{19,20}$ and the caspase-8 (also Fas-associated death domain-like interleukin $1 \beta$-converting enzyme (FLICE)/MACH/Mch5), ${ }^{21-23}$ into a multimolecular signaling plateform named the death-inducing signaling complex (DISC; ${ }^{24}$ ). Further activation of caspase-8 by autoproteolytic cleavage at the DISC level initiates the apoptotic signaling cascade can $^{25,26}$ which can either directly activate effector caspases or trigger the mitochondrial apoptosis loop amplification. ${ }^{27}$ FAS-induced cell death is tightly controlled by proximal regulators, among which is cellular FLICE inhibitory protein (c-FLIP), a procaspase-8-like protease-deficient protein. ${ }^{28-34} \mathrm{c}$-FLIP is mainly expressed as a long (C-FLIP $)$ and a short (c-FLIPS) spliced isoforms, which can be both recruited to the DISC. Similar to caspase-8, $C-F L I P L$ consists of two amino-terminal death effector 
domains (DED) followed by an unfunctional caspase homology domain. ${ }^{35}$ To date, the role of $\mathrm{C}-\mathrm{FLIP}_{\mathrm{L}}$ in apoptosis remains controversial. Indeed, proapoptotic, antiapoptotic and proliferative functions have been reported. ${ }^{35-39}$ In contrast, only antiapoptotic functions have so far been ascribed to $\mathrm{c}-$ FLIP. $_{\mathrm{S}}{ }^{35}$

We had previously shown that E2F1 expression is faintly detectable in human lung adenocarcinomas. ${ }^{40}$ As E2F1deficient mice develop pulmonary adenocarcinoma with a high incidence, ${ }^{10}$ we had postulated that low levels of E2F1 contribute to the carcinogenesis of human lung adenocarcinomas by creating a defective response of tumor cells to apoptotic stimuli. Consistent with such hypothesis, we demonstrate that E2F1 induces apoptosis in various human lung adenocarcinoma cell lines by a mechanism involving a specific downregulation of the c-FLIPs protein, leading to the activation of caspase-8 at the DISC level. Importantly, we also provide evidence that downregulation of c-FLIPs by E2F1 restores tumor cells' sensitivity to death-receptor-mediated apoptosis as well as to T-lymphocyte-mediated cytotoxicity, indicating that E2F1 could regulate the cellular response to the immune system.

\section{Results}

\section{E2F1-induced apoptosis in lung adenocarcinoma cell lines requires caspase- 8 activation and an intact E2F1 DNA-binding domain}

We first tested the ability of E2F1 to trigger apoptosis in A549 and H1299 human lung adenocarcinoma cell lines using transient transfection with a vector encoding wild-type E2F1. As compared to cells transfected with a control vector, enforced E2F1 expression strongly induced apoptosis in both cell lines (Figure 1a). In order to confirm the results of transient transfections, we then established stable E2F1 or E2F1(E132) DNA-binding defective mutant inducible clones in the H358 cell line derived from a human lung adenocarcinoma, using the doxycyclin-inducible expression system (Tet-On). Of note, E2F1 expression was undetectable in H358 cells (Figure 1b, upper panel). Several stable transfectant clones were obtained and were found to give similar results. Therefore, data presented with H358/Tet-On/E2F1 clone 6 and H358/Tet-On/E2F1(E132) clone 22 are representative of all clones tested. As shown in Figure 1b (upper panel), expression of E2F1 and E2F1(E132) proteins was strongly induced after $48 \mathrm{~h}$ of doxycyclin treatment and persisted even after 6 days of continuous induction. In H358/Tet-On/E2F1 cells, apoptosis was clearly detected after $72 \mathrm{~h}$ of doxycyclin treatment and reached $20 \%$ of total cells after 6 days (Figure 1b, lower panel). In contrast, and consistent with previous studies, ${ }^{14,41}$ apoptosis was never observed in H358/Tet-On/E2F1(E132) cells (Figure 1b, lower panel). Appearance of apoptotic cells upon E2F1 expression correlated with the cleavage of procaspase- 8 and -3 in their p43/41 and p17 active fragments, respectively, followed by the activation of procaspase- 6 and -7 (Figure 1c). Interestingly and consistent with previous data, ${ }^{42} \mathrm{E} 2 \mathrm{~F} 1$ also increased procaspase-7 expression level. Of note, activation of this proteolytic cascade was never detected following E2F1(E132) overexpression (data not shown). In order to confirm the involvement of the caspase- 8 initiator and the caspase- 3 effector during E2F1-mediated apoptosis, we finally tested the effect of two specific caspase- 8 and -3 inhibitors, namely z-IETD-fmk and z-VED-fmk, respectively. As shown in Figure $1 \mathrm{~d}$, both inhibitors significantly reversed the ability of E2F1 to induce apoptosis. In contrast, a specific caspase-9 inhibitor (z-LEDH-fmk) had no significant effect and the cytochrome $c$ was never released from mitochondria in response to E2F1 expression, suggesting that the mitochondrial amplification loop was not involved in our model (data not shown). Overall, these results indicate that E2F1 requires an intact DNA-binding domain and caspase-8 and -3 activities to trigger apoptosis in adenocarcinoma cell lines.

\section{E2F1 activates caspase-8 at the DISC level}

Until now, two distinct cellular models of FAS signaling pathway activation have been described. In type I cells, the death signal is initiated by the accumulation of activated caspase-8 at the DISC level. In type II cells, procaspase-8 expression level is low and the caspase cascade requires further amplification through the mitochondrial loop. ${ }^{27}$ The inhibition of E2F1-dependent apoptosis by the z-IETD-fmk caspase-8 inhibitor prompted us to analyze the DISC components. We first observed that E2F1 did not affect FAS, FasL or FADD protein expression, nor increased the amount of the FAS receptor at the membrane (data not shown). Caspase-8 activation at the DISC results mainly from the binding of FasL to the FAS receptor but can also occur in the absence of FasL triggering. ${ }^{4-46}$ To determine whether E2F1-induced cell death involved an interaction between FAS and FasL, we used the antagonistic ZB4 anti-Fas antibody which inhibits FAS/FasL binding. Our data showed that treating cells with increasing concentrations of ZB4 did not modulate the ability of E2F1 to induce apoptosis as detected by Hoechst staining (Figure 2a, left panel) or caspase-3 activation (Figure 2a, right panel). These results suggested that a FAS/FasL interaction did not play a central role in E2F1induced apoptosis. In keeping with these data, we did not detect any FasL secretion into the culture medium, nor a modulation of FasL expression on the membrane in response to E2F1 (data not shown). In order to analyze the DISC, FAS co-immunoprecipitation experiments were performed in H358/Tet-On/E2F1 clones. E2F1 induction led to the recruitment of FADD, caspase- 8 and caspase-10 at the FAS DISC (Figure $2 b$ ). Importantly, the procaspase-8 was activated as reflected by the appearance of its $p 43 / 41$ active fragments in FAS co-immunoprecipitates (Figure $2 b$ ). In addition, FAS and FADD were found to co-immunoprecipitate with caspase-8 in E2F1-expressing cells when immunoprecipitation experiments were performed using an antibody against caspase-8 (data not shown). In this context, we were unable to detect FasL at the DISC that was consistent with FasL binding being not essential for FAS activation in response to E2F1. Finally, as DISC formation and caspase-8 activation stimulate the clustering of the FAS receptor at the cell surface, ${ }^{47}$ we used confocal laser scanning microscopy to further analyze the FAS receptor subcellular distribution in our cells. As expected from our co-immunoprecipitation experiments, E2F1 induced 
a

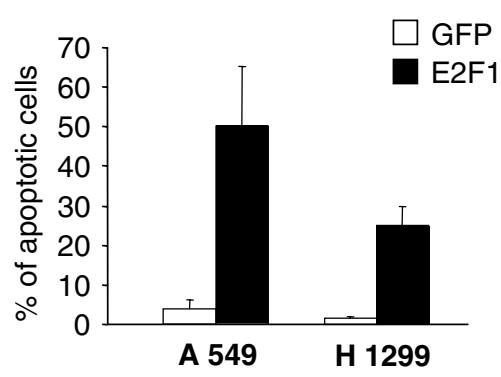

C

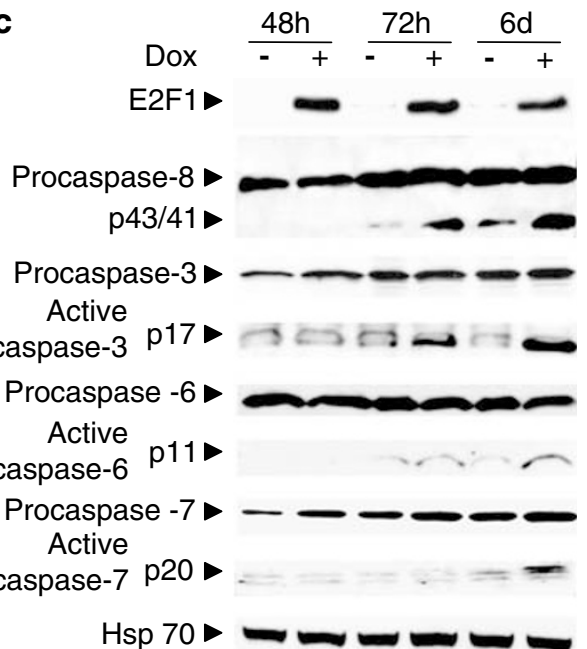

b
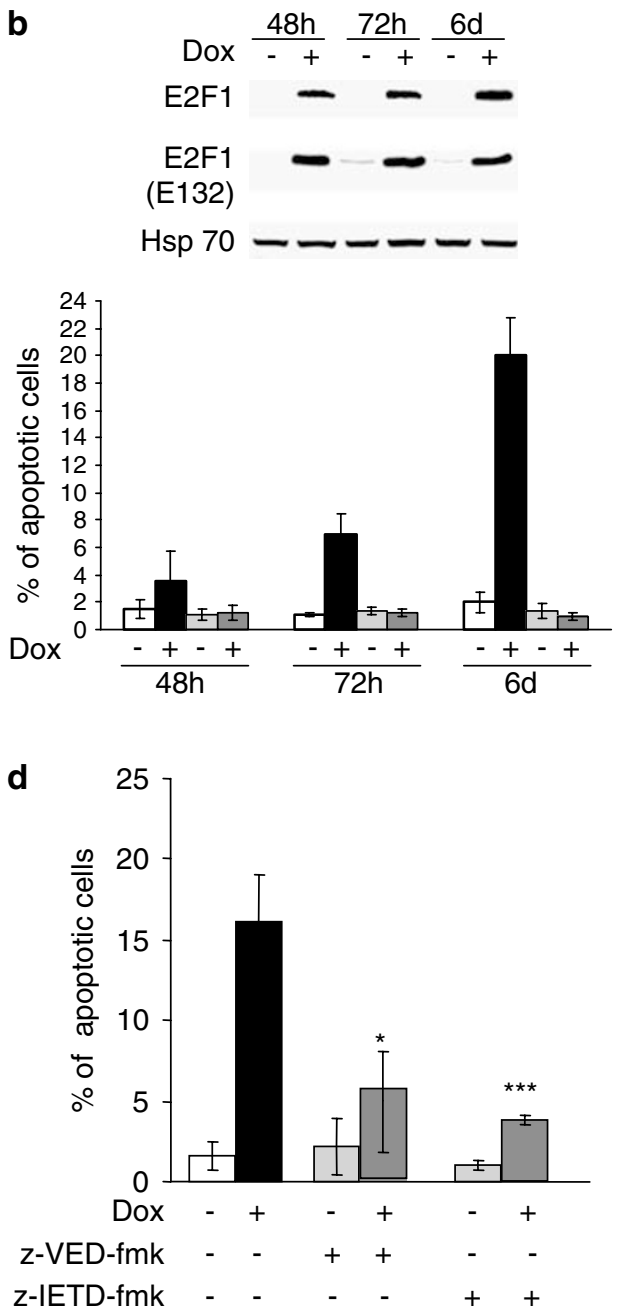

Figure 1 E2F1 induces apoptosis in lung adenocarcinoma cells through a caspase-8- and DNA-binding domain-dependent mechanism. (a) A549 and H1299 cell lines were transfected either with a control pcDNA3.1/GFP (open bars) or a pcDNA3.1/E2F1 (closed bars) vector. Apoptosis was monitored after 6 days of geniticin selection, in GFP- or E2F1-positive cells using Hoechst 33342 staining. Results are the mean \pm S.D. of three independent experiments. (b) Western blot analysis (upper panel) and percentage of apoptotic cells (lower panel) in H358/Tet-On/E2F1 (white and black bars) or H358/Tet-On/E2F1(E132) (hatched white and black bars) cells cultured in the presence (Dox + ) or absence (Dox-) of doxycyclin for the indicated times. Results are the mean \pm S.D. of three independent experiments. (c) Western blot analysis of caspases in H358/Tet-On/E2F1 cells cultured in the presence (Dox + ) or absence (Dox-) of doxycyclin for the indicated times. HSP 70 was used as a loading control. (d) H358/Tet-On/E2F1 cells were pretreated or not for $2 \mathrm{~h}$ with $2 \mu \mathrm{M}$ of either Z-VED-fmk or Z-IETD-fmk, then $1 \mu \mathrm{g} / \mathrm{ml}$ doxycyclin was added (Dox + ) or not (Dox-) in the culture medium and cells were further cultured for 6 days. Percentage of apoptotic cells was scored on 500 cells after Hoescht staining. Results are the mean \pm S.D. of three independent experiments. ${ }^{*} P<0.05 ;{ }^{* * \star} P<0.001$ by Student's $t$ test

the clustering of FAS, whereas E2F1(E132) did not (Figure 2c). Overall, these results demonstrate that E2F1 activates the DISC of the FAS receptor.

\section{E2F1 downregulates c-FLIPS protein expression to induce apoptosis}

As our results indicated that E2F1 triggered cell death by affecting downstream effectors of the FAS signaling pathway, we then focused on the proximal regulators of procaspase- 8 activation at the DISC level. c-FLIP is a specific endogenous caspase-8 inhibitor. ${ }^{32}$ Both c-FLIP long (c-FLIP $)$ and c-FLIP short (c-FLIPS) isoforms can be incorporated into the DISC and inhibit specific steps of caspase-8 activation. ${ }^{35}$ Consequently, elevated levels of c-FLIP protein protect cells from death-receptor-mediated apoptosis. Interestingly, E2F1 but not E2F1(E132) induction was associated with a modest increase and a strong decrease of $c-F L I P L$ and $c$-FLIPs protein levels, respectively (Figure 3a). These effects correlated with the appearance of apoptosis $72 \mathrm{~h}$ postinduction and persisted even after 6 days of doxycyclin treatment. Of note, E2F1 expression also stimulated the cleavage of c-FLIP $\mathrm{P}_{\mathrm{L}}$ into its $\mathrm{p} 43$ fragment. In the context where E2F1induced apoptosis requires the specific downregulation of

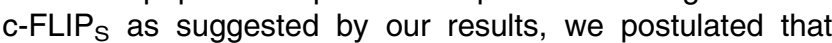
ectopic expression of $\mathrm{c}-\mathrm{FLIP}$ s could block E2F1-mediated programmed cell death. To test this hypothesis, H358/Tet-On/ 
a

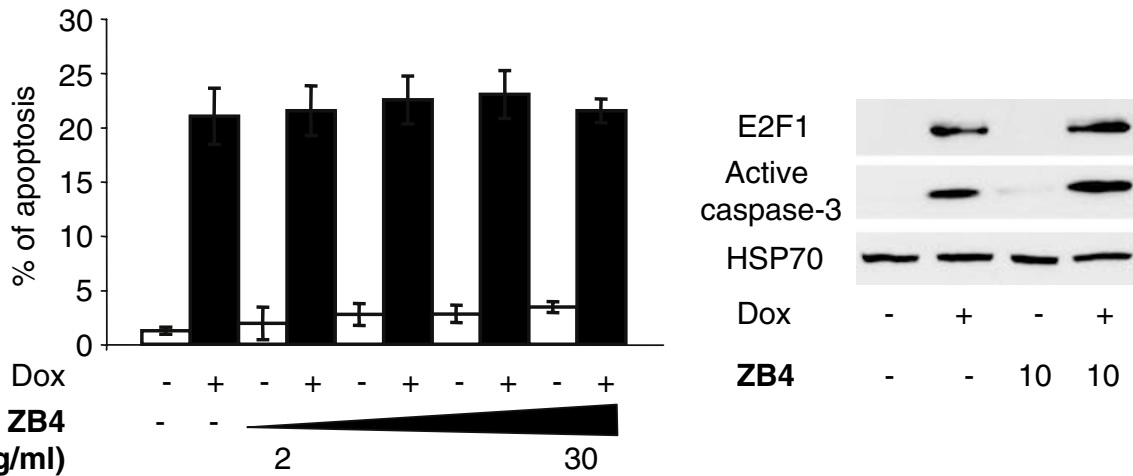

b

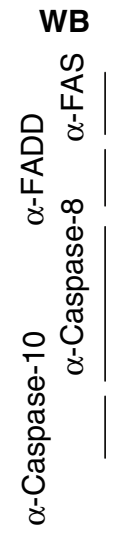

C

FasL-treated HT29 cells

FAS

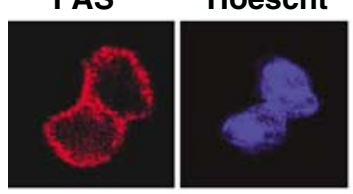

IP

FAS

Inputs

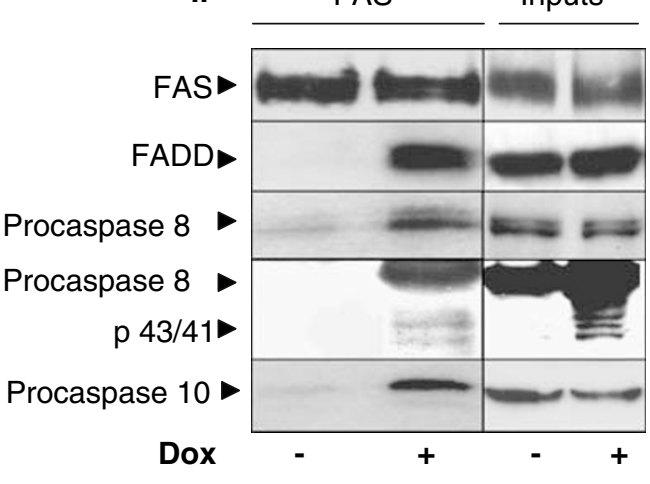

Shorter exposure

Longer exposure

E2F1
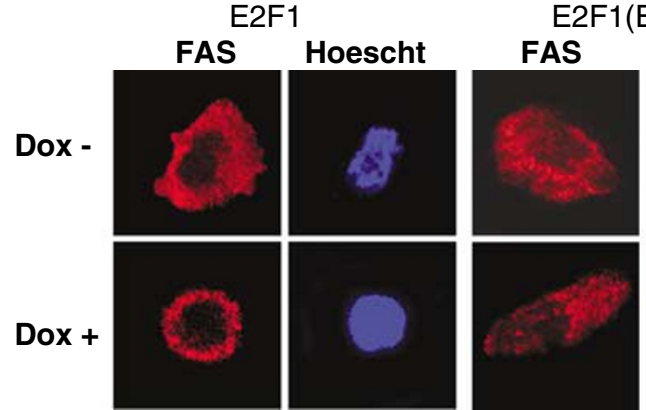

E132)

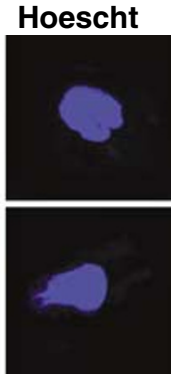

Figure 2 E2F1 activates caspase-8 at the DISC level. (a) H358/Tet-On/E2F1 cells were cultured for 6 days in the presence $(+)$ or absence $(-)$ of doxycyclin (Dox) and/or increasing concentrations (2, 5, 10 and $30 \mu \mathrm{g} / \mathrm{ml}$ ) of antagonistic anti-FAS mAb (ZB4). Left panel: Apoptosis was scored on 500 cells after Hoechst staining. Right panel: Activation of caspase-3 was detected after immunoblotting. (b) H358/Tet-On/E2F1 cells were cultured in the presence (Dox + ) or absence (Dox-) of doxycylin for 6 days. FAS immunoprecipitates were analyzed for the presence of the components of the DISC by immunoblotting using specific antibodies. For all experiments, inputs are representative of $80 \mu \mathrm{g}$ of whole-cell extracts. (c) Confoncal laser microscopy analysis of FAS subcellular distribution was performed in H358/Tet-On/E2F1 and H358/Tet-On/E2F1(E132) cells cultured for 6 days in the presence (Dox + ) or absence (Dox-) of doxycyclin. Magnification amplitude: $\times 60$. HT29 cells treated with FasL were used as a positive control

E2F1 cells were stably infected with a VSV-FLIPshort (FLIPS) expression vector or a control mock vector. As compared to

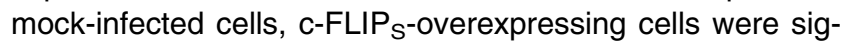
nificantly more resistant to apoptosis induced by E2F1 (Figure 3b). In contrast, silencing of c-FLIPs using RNA interference in $\mathrm{H} 358 / \mathrm{Tet}-\mathrm{On} / \mathrm{E} 2 \mathrm{~F} 1$ cells enabled a three-fold increase in the percentage of apoptotic cells upon E2F1 expression (Figure 3c). Interestingly, this was detected after $48 \mathrm{~h}$ of E2F1 induction. Taken together, these results demonstrate that C-FLIP is a potent inhibitor of E2F1-induced apoptosis. Importantly, c-FLIP protein expression was also specifically increased in E2F1-deficient murine embryonic fibroblasts (MEFs) as compared to wild-type MEFs, while
C-FLIP $\mathrm{P}_{\mathrm{L}}$ status was not affected (Figure $3 \mathrm{~d}$ ). These results indicate that C-FLIP is also an E2F1 target in primary cells.

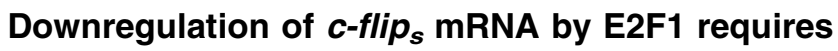 protein synthesis}

We further investigated the molecular mechanisms involved in E2F1-mediated c-FLIP downregulation. To this end, we used RT-PCR to analyze the effect of E2F1 on $c$-flip, and $c$-flip mRNA levels. As shown in Figure 4a, expression of E2F1

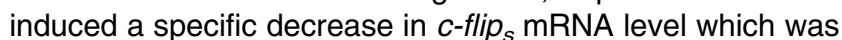
detected upon $72 \mathrm{~h}$ of doxycyclin treatment, whereas $c$-flip, 
a

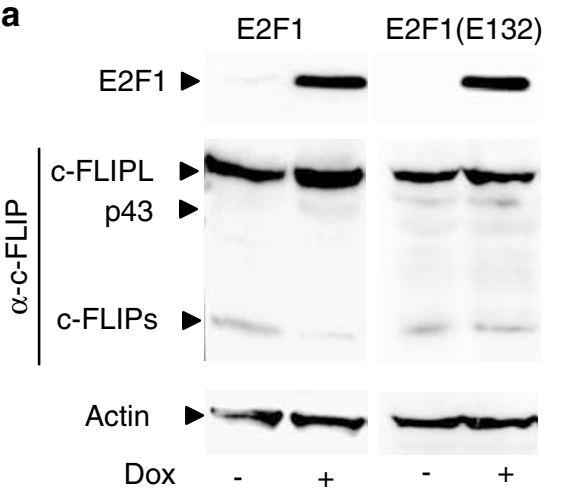

C
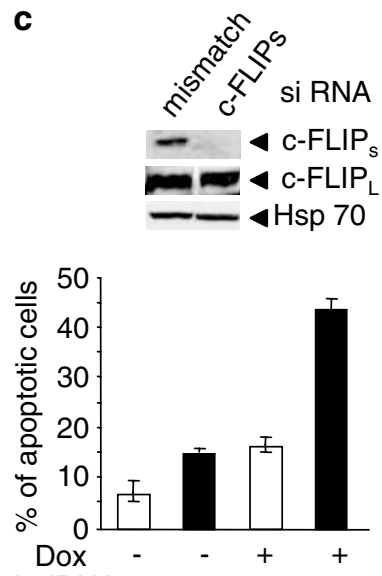

mismatch siRNA + - + -

$c$-flips siRNA - +-+ b

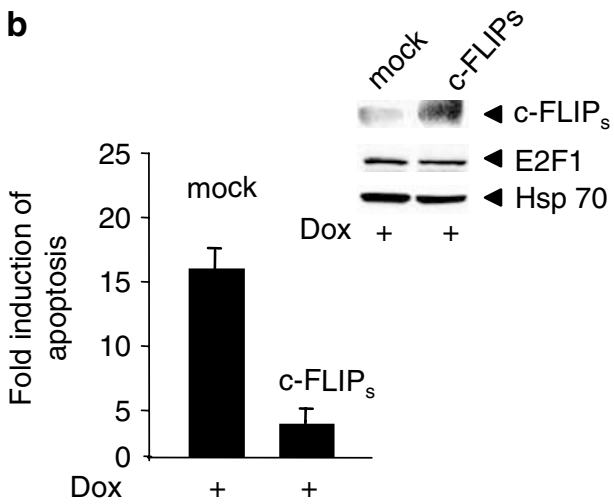

d

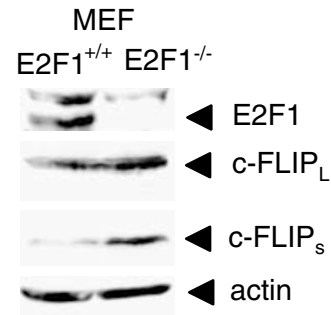

Figure 3 The short isoform of c-FLIP is a downstream target of E2F1. (a) Western blot analysis of c-FLIP isoforms was performed in H358/Tet-On/E2F1 (left panels) and H358/Tet-On/E2F1(E132) (right panels) cells cultured for 6 days in the presence (Dox + ) or absence (Dox-) of doxycyclin. Actin was used as a loading control. (b) Apoptosis was analyzed in H358/Tet-On/E2F1 cells stably infected with either control (mock) or c-FLIPs-expressing vectors (c-FLIPs) and cultured for 6 days in the presence or absence of doxycyclin. Fold induction of apoptosis represents the ratio: percentage of induced apoptotic cells/percentage of uninduced apoptotic cells. Results are the mean \pm S.D. of three independent experiments. Western blot analysis confirmed overexpression of c-FLIPs protein in VSV-FLIP - transfected cells as

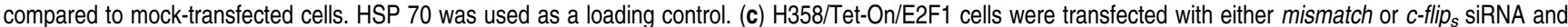
cultured in the presence (Dox + ) or absence (Dox-) of doxycyclin. Apoptosis was scored on at least 500 cells using Hoechst staining. Results are the mean \pm S.D. of three independent experiments. Western blotting confirmed the neutralization of c-FLIP by siRNA. HSP 70 was used as a loading control. (d) Western blot analysis of

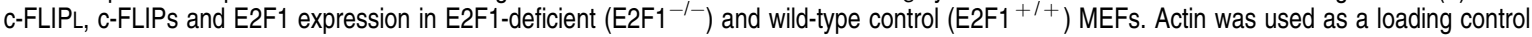

mRNA level remained unaffected. In the same conditions, E2F1(E132) expression did not affect mRNA level of both $c$-flip and $c$-flip, confirming the requirement of the E2F1 DNAbinding domain to regulate c-FLIPs. Importantly, E2F1 was not able anymore to downregulate $c$-flip $p_{s}$ mRNA level in the presence of cycloheximide, a protein synthesis inhibitor, indicating that de novo protein synthesis is required for

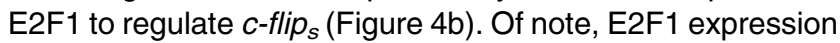
level was not affected by the cycloheximide treatment in our conditions (data not shown).

\section{E2F1 sensitizes NSCLC cells to death-receptor- mediated apoptosis}

Our data demonstrated that E2F1 overexpression was sufficient to activate the FAS signaling pathway by affecting $\mathrm{C}^{-}$FLIP $_{\mathrm{S}}$ expression, even in the absence of death receptor ligands. As the role of endogenous c-FLIP proteins, and more specifically of c-FLIP , in resistance to FAS-related apoptosis had been established, ${ }^{32}$ we tested whether E2F1 could affect the response of lung adenocarcinoma cells to death receptor stimuli. Using transient transfections, we first demonstrated that E2F1 overexpression sensitized $\mathrm{A} 549$ and $\mathrm{H} 1299$ cells to apoptosis induced by the agonistic FAS $\mathrm{CH} 11 \mathrm{mAb}$ as compared to control-transfected cells (Figure 5a). Same results were observed in H358/Tet-On/E2F1 clones which became sensitive to $\mathrm{CH} 11$ treatment in the presence of E2F1 (Figure 5b, upper). In contrast, E2F1(E132)-expressing cells remained highly resistant (Figure $5 \mathrm{~b}$, upper panel). Furthermore, E2F1-expressing cells were also more sensitive to FasL and TRAIL treatments as compared to uninduced or E2F1(E132)-expressing cells (Figure 5b, lower panel). Interestingly, E2F1 did not increase the cytotoxic effects of etoposide or paclitaxel (Figure 5c), indicating that E2F1 specifically sensitized $\mathrm{H} 358$ cells to death receptor stimuli. 
a

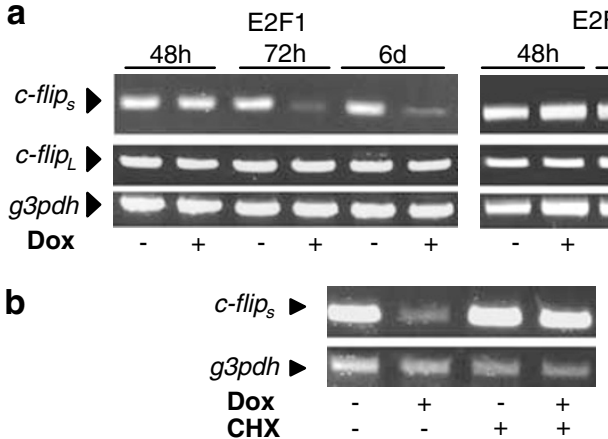

Figure 4 E2F1 specifically downregulates $c$-flip $s_{s}$ mRNA. (a) RT-PCR analysis of $c$-flip $p_{s}$ or $c$-flip, RNA expression level was performed in H358/Tet-On/E2F1 (left panel) or H358/Tet-On/E2F1(E132) (right panel) cells cultured in the presence $($ Dox + ) or absence (Dox-) of doxycyclin for the indicated times. Amplified G3PDH was used as an internal control. (b) H358/Tet-On/E2F1 cells were cultured in the presence (Dox + ) or in the absence (Dox-) of doxycyclin for $72 \mathrm{~h}$ and cycloheximide $(10 \mu \mathrm{g} / \mathrm{ml})$ was added to the culture $12 \mathrm{~h}$ prior cells harvesting. $c$-flip ${ }_{s}$ RNA expression level was analyzed as described in (a). Results shown are representative of three independent experiments

Importantly, these effects were not restricted to lung adenocarcinoma cell lines. Indeed, we demonstrated that E2F1 ${ }^{-1}$ MEFs were more resistant to FasL or TRAIL treatment than wild-type MEF (Figure 5d), although they expressed the same level of FAS and DR5 at the membrane (data not shown). These results supported the idea that endogenous E2F1 affects the FAS death pathway downstream of the receptor level.

\section{Neutralization of C-FLIPs restores the sensitivity of tumor cells and primary $\mathrm{E2F} 1^{-1-}$ MEFs to death-receptor-mediated apoptosis}

Finally, we asked whether downregulation of c-FLIPs was sufficient to restore cells' sensitivity to apoptosis triggered by death receptors stimuli. As shown in Figure $6 a, c$-flip $p_{s}$ transfected $\mathrm{E} 2 \mathrm{~F} 1^{-1-}$ MEFs became sensitive to FasL- and TRAIL-mediated apoptosis as compared to mismatch-transfected cells. These results indicated that overexpression of c-FLIPs in E2F1-deficient cells contributes to their resistance to death receptor stimuli. In the same way, neutralization of

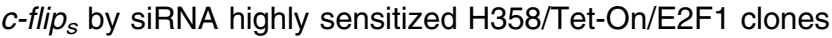
to $\mathrm{CH} 11$ or TRAIL treatment when compared to cells transfected with mismatch siRNA (Figure 6b). Interestingly, concomittant E2F1 induction in the same cells did not significantly potentiate the effect of $c$-flip $p_{s}$ neutralization. These results indicate that E2F1 sensitizes these tumor cells to death-receptor-mediated apoptosis mainly through c-FLIPS downregulation.

\section{E2F1 enhances tumor cell sensitivity to T-lymphocyte-mediated cytotoxicity}

FAS/FasL interactions and perforin/granzyme B pathways are the two main lytic mechanims used by cytotoxic T cells. ${ }^{48,49}$ Recent data provided evidence that an immune response might occur in NSCLCs and especially that effector T cells might contribute to tumor regression. ${ }^{50}$ In addition, it was demonstrated that c-FLIP protein expression enabled tumor cells to escape from T-cell immunity in vivo, ${ }^{51,52}$ Since we established that E2F1 regulated the cellular response to death receptor stimuli by downregulating c-FLIP , we next tested its ability to sensitize H358 cancer cells to cytolytic T cells. To do so, a T-lymphocyte-mediated cytotoxic assay was set up in the presence of EGTA, which blocks the perforin pathway. In this context, the cellular lysis is strictly dependent on a functional FAS/FasL interaction. The Jurkat T cells expressing high levels of the FAS receptor were used as positive control of effective lysis by activated T lymphocytes (Figure 7). When H358/Tet-On/E2F1 cells cultured for $72 \mathrm{~h}$ in the presence or absence of doxycyclin were used as targets, the lysis mediated by cytotoxic $T$ cells was significantly increased in E2F1-expressing cells as compared to uninduced cells (Figure 7). Therefore, we concluded from these data that E2F1 also enhances the response of tumor cells to the T-lymphocyte-dependent cytotoxicity.

\section{c-FLIPs is overexpressed in human lung adenocarcinomas}

Finally, we investigated whether the c-FLIPS isoform is deregulated in human lung adenocarcinomas which display undetectable E2F1 protein expression. ${ }^{40}$ To this end, we analyzed E2F1 and C-FLIP protein expression by Western blotting on 12 tumor samples and five matched normal lung tissues. Representative results from five normal/tumor couples are presented in Figure 8 but same data were obtained in the seven remaining tumor samples. Consistent with our previous study, ${ }^{40}$ E2F1 protein expression was hardly detectable in the tumor samples. Interestingly, c-FLIPS protein expression was strongly enhanced in these samples as compared to normal lung tissues, whereas C-FLIP protein expression was not altered (Figure 8). Overall, these results show that c-FLIPS is specifically overexpressed in lung adenocarcinomas. Moreover, they provide evidence that both c-FLIP protein isoforms can be differentially expressed. Of note, as normal lung tissues do not overexpress c-FLIPs despite a low level of E2F1 expression, it is likely that additional signals cooperate with E2F1 loss to induce c-FLIPS overexpression in lung adenocarcinomas.

\section{Discussion}

A large body of evidence has established that apoptosis can occur through both intrinsic (caspase-9 mediated) and extrinsic (caspase- 8 mediated) death pathways. The ability of E2F1 to promote apoptosis by activating the intrinsic pathway has been well documented, notably through transcriptional activation of apaf-1 or caspase-9 genes (for review, see Ginsberg ${ }^{15}$ ). In contrast, the relationships between E2F1 and the extrinsic pathway have been less studied. Here, we demonstrate that E2F1 triggers apoptosis in various human lung adenocarcinoma cell lines by a mechanism involving the transcriptional inhibition of $c$-flip $p_{s}$ thus leading to the activation of caspase-8 at the DISC level. Importantly, we find that c-FLIPS protein is specifically overexpressed in lung adeno- 
a

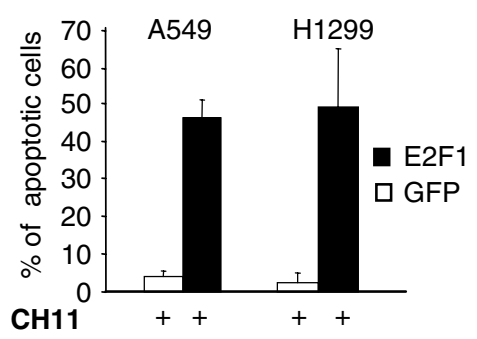

C b
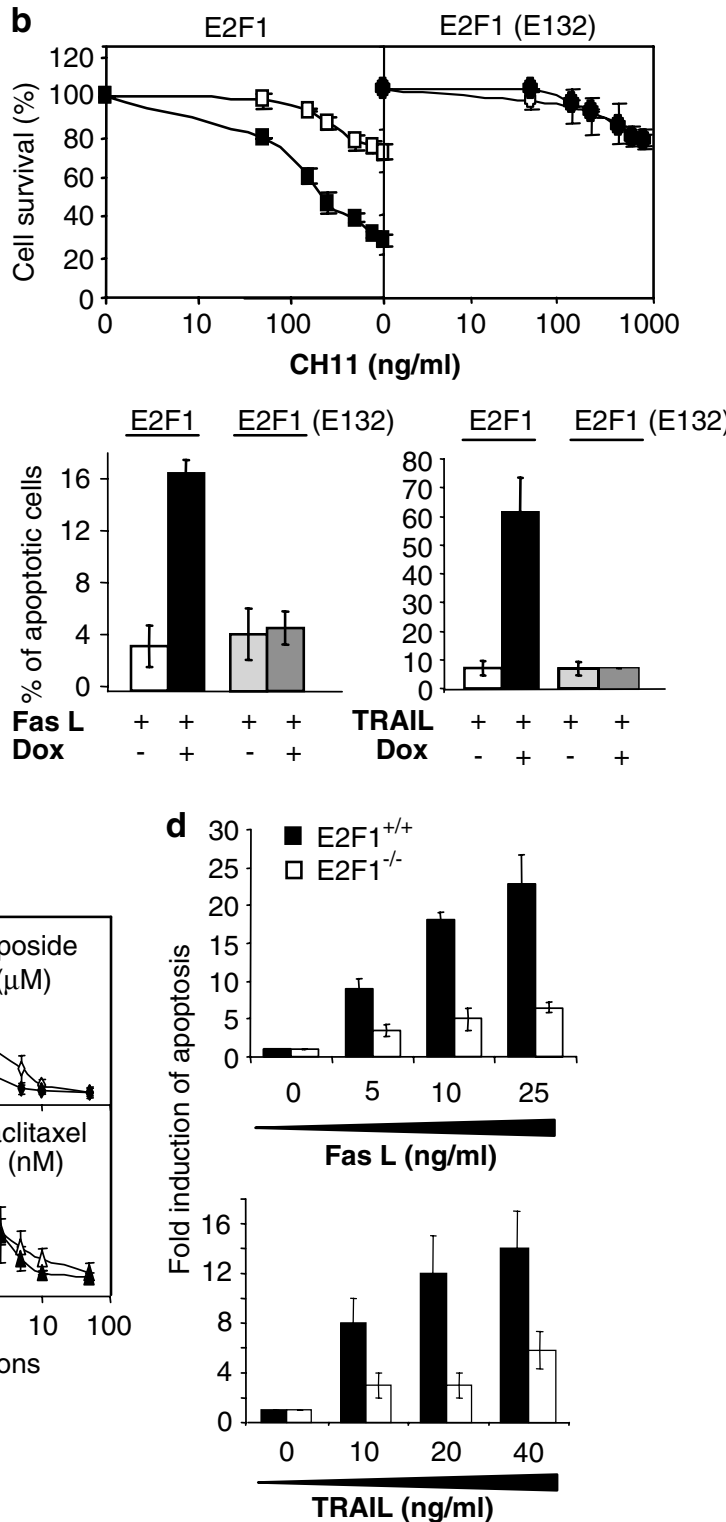

Figure 5 E2F1 sensitizes NSCLC cells to death-receptor-mediated apoptosis. (a) A549 and H1299 cell lines were transfected with either a control pcDNA3.1/GFP (open bars) or a pcDNA3.1/E2F1 (black bars) vector and treated with agonistic anti-Fas CH11 mAb (250 ng/ml). Apoptosis was assessed in GFP- or E2F1-positive cells using Hoechst 33342 staining after 6 days of geniticin selection. Results are the mean \pm S.D. of three independent experiments. (b) Upper panel: a 96-h cell viability assay was performed in H358/Tet-On/E2F1 or H358/Tet-On/E2F1(E132) cells cotreated with (Dox + ; black symbols) or without (Dox-; white symbols) doxycyclin and increasing amounts of the FAS agonistic $\mathrm{CH} 11 \mathrm{mAb}$. Results are expressed as the percentage of cell survival as compared to untreated cells. Mean values of three independent experiments \pm S.D. performed in triplicate are presented. Lower panel: H358/Tet-On/E2F1 and H358/Tet-On/E2F1(E132) cells were treated or not with 293 FasL supernatants or $40 \mathrm{ng} / \mathrm{ml}$ TRAIL, in the presence (Dox + ) or absence (Dox-) of doxycyclin for $72 \mathrm{~h}$. Percentage of apoptotic cells was monitored after Hoescht staining. Results are the mean \pm S.D. of three independent experiments. (c) A 96-h cell viability assay was performed in H358/Tet-On/E2F1 cells cotreated with (Dox + ; black symbols) or without (Dox-; white symbols) doxycyclin and increasing amounts of either etoposide or paclitaxel as indicated. Results are expressed as the percentage of cell survival as compared to untreated cells. Mean values of three independent experiments \pm S.D. performed in triplicate are presented. (d) E2F1deficient (E2F1 $1^{-l-}$, white bars) and wild-type control ( $\mathrm{E} 2 \mathrm{~F} 1^{+l+}$, black bars) MEFs were treated for $24 \mathrm{~h}$ with increasing amounts of FasL or TRAIL and apoptosis was evaluated using Hoescht staining. Fold induction of apoptosis represents the ratio: percentage of apoptotic treated cells/percentage of apoptotic untreated cells

carcinoma, which display a low level of E2F1 expression, and provide evidence that E2F1 restores tumor cells' sensitivity to death-receptor stimuli, by downregulating c-FLIPS expression. Overall, our data identify a new mechanistic link between E2F1 and the death-receptor signaling pathway and suggest that downregulation of E2F1 expression level contributes to the immune escape of lung adenocarcinoma tumor cells.
E2F1 can induce apoptosis via several p53-dependent or independent mechanisms, either through direct transactivation of proapoptotic genes such as $p 73,{ }^{53,54}$ apaf- 1 (apoptosis protease-activating factor 1$)^{55,56}$ and caspase ${ }^{42}$ or transcriptional repression. ${ }^{14,41}$ Here, we show that E2F1 is able to induce a p53-independent apoptosis through the downregulation of the c-FLIP ${ }_{S}$ antiapoptotic protein. So far, a few 
a
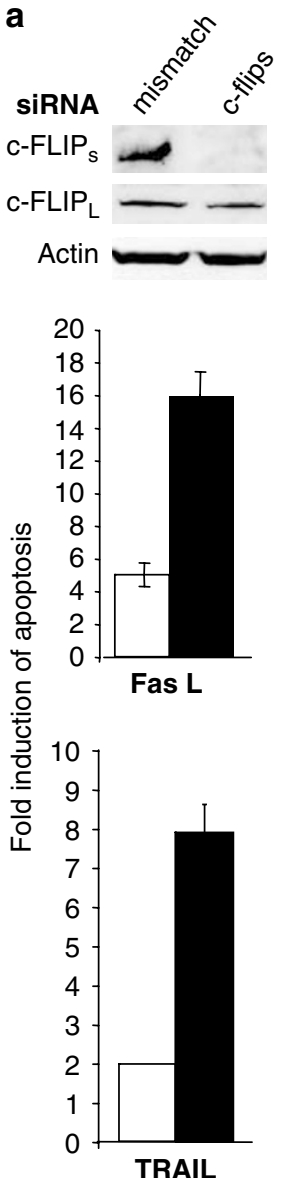

b
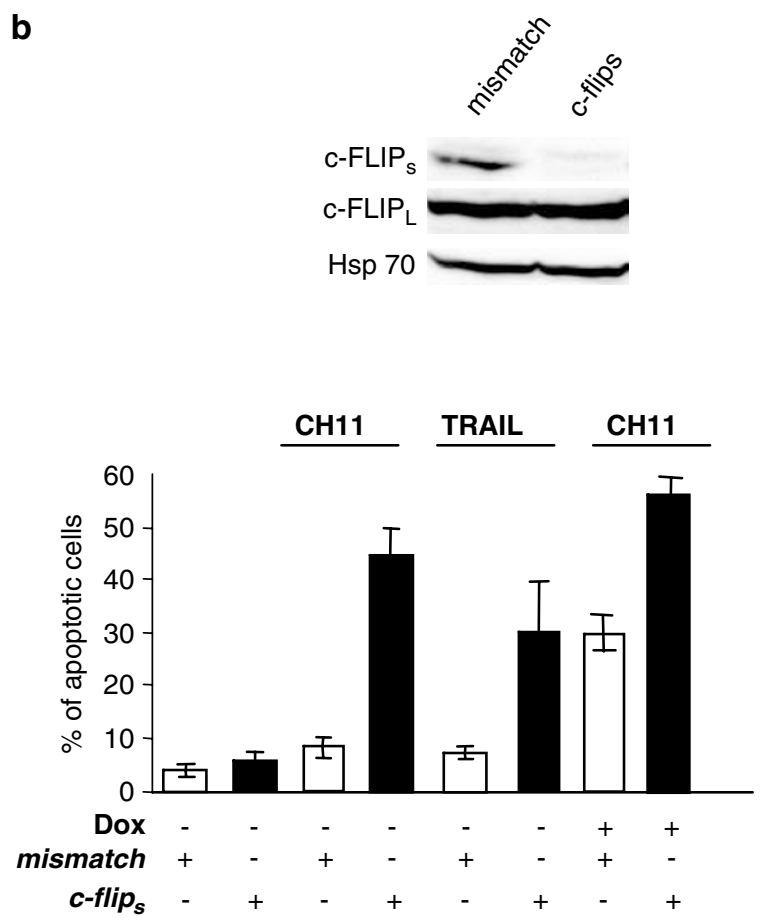

Figure 6 Downregulation of C-FLIP is sufficient to restore tumor cell and primary E2F1 ${ }^{-1-} \mathrm{MEF}$ sensitivity to death-receptor-mediated apoptosis. (a) E2F1 ${ }^{-1-} \mathrm{MEFs}$ were transfected for $50 \mathrm{~h}$ with mismatch (white bars) or $c$-flip (black bars) siRNA, then treated or not with $25 \mathrm{ng} / \mathrm{ml}$ FasL or $40 \mathrm{ng} / \mathrm{ml} \mathrm{Killer} \mathrm{TRAlL}^{\text {TM }}$ for 20 additional hours. Apoptosis was evaluated using Hoechst staining. Fold induction of apoptosis represents the ratio: percentage of apoptotic treated cells/percentage of apoptotic untreated cells in each condition. Upper blot: Immunoblotting experiments showing the neutralization of c-FLIP $P_{S}$ in $c$-flip $p_{s}$-transfected cells as compared to mismatchtransfected cells. Actin was used as a loading control. (b) H358/Tet-On/E2F1 cells were transfected either with mismatch or c-flip $p_{s}$ siRNA and treated or not with $500 \mathrm{ng} /$ $\mathrm{ml}$ anti-FAS CH11 mAb or $100 \mathrm{ng} / \mathrm{ml}$ TRAlL for $5 \mathrm{~h}$ as indicated. In some experiments, E2F1 was induced by doxycyclin treatment. Percentage of apoptotic cells was assessed using Hoescht staining. Results shown are the mean \pm S.D. of three independent experiments. Western blot analysis demonstrates the specific downregulation of C-FLIPS protein expression. HSP70 was used as a loading control

studies have reported a link between E2F1 and the deathreceptor signaling machinery. ${ }^{16,17,57-59}$ In this work, we found that E2F1 activates the proteolytic cleavage of caspase-8 at the DISC and induces the clustering of the FAS receptor. We also found that ZB4, an antagonistic antibody that blocks FAS/ FasL interaction, does not inhibit E2F1-induced apoptosis. In addition, we were unable to detect FasL at the DISC in our coimmunoprecipitation experiments. These results suggest that FasL binding is not required for FAS activation in response to E2F1. Such model in which death receptors are activated without the need of their respective death ligand has been previously reported in a context of UVB exposure. ${ }^{44}$ However, as E2F1-induced apoptosis was a progressive process in our model with $20 \%$ of apoptotic cells at the time of immunoprecipitation, we cannot exclude that only a small fraction of FAS molecules are clustered and activated at each time making difficult FasL detection in co-immunoprecipitation studies.
More importantly, we showed that caspase- 8 activation by E2F1 is specifically associated with the downregulation of c-FLIPS. Originally, c-FLIP proteins were solely considered as inhibitors of death receptor-induced apoptosis, functioning as procaspase-8 competitors for binding to FADD at the activated DISC. ${ }^{60-62}$ In this context, c-FLIPS appeared to be more efficient than $C$-FLIPL. ${ }^{31,33,63-65}$ Interestingly, recent works showed that recruitement of $C-F L I P_{L}$ to the DISC could also promote caspase-8 activation. ${ }^{36-38}$ In our cells, we never detected the presence of $\mathrm{C}-\mathrm{FLIP}_{\mathrm{L}}$ at the DISC level. Thus, it is tempting to speculate that E2F1, by altering the stoechiometry of $\mathrm{C}-\mathrm{FLIP}_{\mathrm{S}}$ and $\mathrm{C}-\mathrm{FLIP}_{\mathrm{L}}$ molecules, enables activation of caspase-8 at the DISC and triggers programmed cell death. However, as c-FLIP neutralization does not induce apoptosis on its own in our cells, E2F1 probably activates other collateral signals that collaborate with the downregulation of c-FLIP to trigger caspase-8 activation and cell death. Interestingly, it 


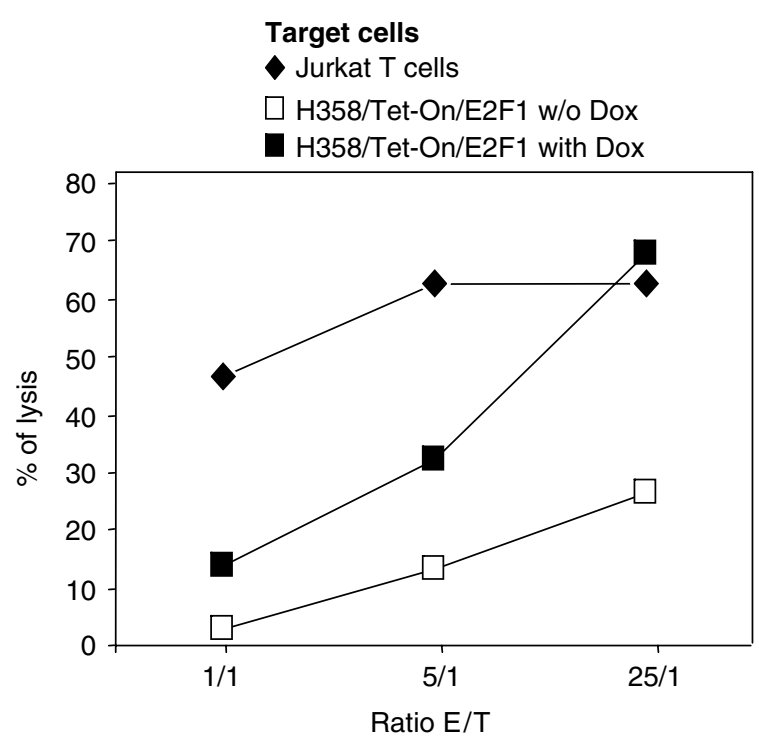

Figure 7 E2F1 enhances tumor cells' sensitivity to T-lymphocyte-dependent cytotoxicity. T-cell-dependent cytotoxicity was measured in the presence of EGTA using a $24 \mathrm{~h}^{51} \mathrm{Cr}$-release assay. Jurkat T cells were used as positive target control cells. H358/Tet-On/E2F1 cells were cultured in the absence or presence of doxycyclin for $72 \mathrm{~h}$ and then used as target cells. Results represent the percentage of cell lysis in function of $E / T$ ratio where $E=$ effector $T$ cells and $\mathrm{T}=$ target cells. Results are representative of two independent experiments

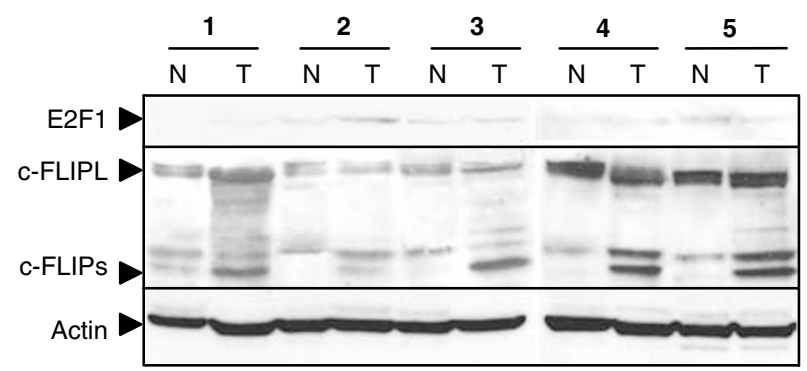

Figure 8 Western blot analysis of E2F1 and c-FLIP expression in human lung adenocarcinoma and their matched normal lung tissues. Western blot analysis of E2F1 and c-FLIP expression in five representative adenocarcinoma lung tumor $(\mathrm{T})$ and their matched normal lung (N). Actin was used as a loading control

was recently shown that loss of $\mathrm{Rb}-\mathrm{E} 2 \mathrm{~F}$ repression resulted in caspase-8-mediated apoptosis through inactivation of focal adhesion kinase. ${ }^{66}$

Both c-FLIP isoforms arise from alternative splicing and until now, the molecular mechanisms controlling their relative expression remain largely unknown. It has been demonstrated that the level of cellular FLIP is regulated both at transcriptional and post-traductional levels, the latter involving the ubiquitin-proteasome pathway. ${ }^{67,68}$ In this study, we demonstrated that E2F1 differentially affects the expression of $\mathrm{C}-\mathrm{FLIP}$ S and $\mathrm{C}-\mathrm{FLIP}_{\mathrm{L}}$ proteins in human cell lines. Furthermore, we also showed the existence of a distinct expression pattern of the two isoforms in a few samples of human lung adenocarcinoma. Altogether, these results are consistent with the notion that $\mathrm{C}-\mathrm{FLIPS}$ and $\mathrm{C}-\mathrm{FLIP}_{\mathrm{L}}$ are differentially regulated and exhibit distinct functions. The FLIP gene was previously reported to be upregulated by E2F $1 .{ }^{69} \mathrm{In}$ contrast, we found that E2F1 induces a specific decrease of $c$-flip $s_{s}$ mRNA level by a mechanism requiring its DNA-binding domain indicating that E2F1 is able to regulate the expression of $\mathrm{C}$-FLIP proteins in various way depending on the cellular context. As both c-FLIP and $\mathrm{c}-\mathrm{FLIP}$ are expressed from the same promoter, our data are not consistent with a model in which E2F1 binds to the FLIP promoter and downregulates specifically $c$-flip $p_{s}$ mRNA without affecting $c$-flip $p_{L}$ mRNA. However, it remains possible that E2F1 binds to the FLIP promoter and recruits some specific cofactors to differentially regulate the alternative splicing of both isoforms, or affects the expression level of proteins controlling the alternative splicing of $c$-flip. Alternatively, E2F1 could also specifically decrease the stability of $c$-flip mRNA. We are currently testing these hypotheses. Of note, we observed that pretreatment of cells with proteasome inhibitors did not prevent the ability of E2F1 to downregulate C-FLIPS (data not shown), indicating that additional c-FLIPS control at the protein level is not involved in our model.

We provided evidence that E2F1 sensitized primary and tumor cells to FasL- or TRAIL-mediated apoptosis. Such enhanced resistance to Fas-triggered apoptosis has been already described in $\mathrm{E} 2 \mathrm{~F} 1^{-1-}$ cerebellar granule neurons, ${ }^{17}$ thymocytes ${ }^{59}$ and lymphocytes. ${ }^{16}$ Altogether, these data are consistent with E2F1 being a critical determinant of the cellular response to death-receptor activation, at least in some cellular types. In addition, this is to our knowledge the first study demonstrating the involvement of E2F1 in the cellular response to TRAIL. High c-FLIP expression has been found in many tumor cells and was correlated with resistance to CD95and TRAIL-induced apoptosis. ${ }^{60}$ Recently, a genetic screen identified that the C-FLIPS isoform conferred resistance to TRAIL in sensitive cells. ${ }^{70}$ Furthermore, $c$-FLIP $P_{S}$ was reported to be more efficient than $C-F L I P_{L}$ in the inhibition of CD95mediated apoptosis in T cells. ${ }^{71}$ Interestingly, E2F1-deficient mice accumulate mature $T$ cells due to a defect in thymocyte apoptosis and negative selection, ${ }^{11,12}$ a process functioning mainly through death-promoting ligands. Whether c-FLIP is overexpressed in $\mathrm{E} 2 \mathrm{~F}^{-1-}$ thymocytes remains to be determined. In our model, selective neutralization of C-FLIPS by siRNA was sufficient to restore tumor cells' sensitivity to both Fas- and TRAIL-mediated apoptosis and concomitant induction of E2F1 in these cells did not lead to an additive effect. Therefore, these data are in favor of E2F1 sensitizing these tumor cells to death-receptor-mediated apoptosis mostly

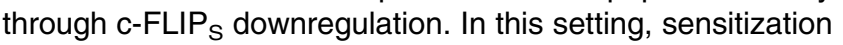
is likely to be mediated by a facilitated caspase- 8 activation in the absence of c-FLIPS. In addition, as we demonstrate that $c$-flip $s_{s}$ neutralization in $\mathrm{E} 2 \mathrm{~F} 1^{-1-} \mathrm{MEF}$ is sufficient to restore their sensitivity to FasL and TRAIL, our results extend to nontransformed cells the role of E2F1 as a determinant of cellular response to death-receptor-mediated apoptosis through $\mathrm{c}-\mathrm{FLIP}_{\mathrm{S}}$ regulation. The death receptor pathway represents one of the mechanisms by which immune cells kill target tumor cells. In this context, we also provided evidence that E2F1 enhanced tumor cell sensitivity to T-lymphocytemediated cytotoxicity. Interestingly, c-FLIP expression was associated with tumor escape from T-cell immunity and 
enhanced tumor progression in 'in vivo' experimental studies pointing to a role of FLIP as a tumor progression factor. ${ }^{51,52,72}$

Many tumors are resistant to Fas- and TRAIL-induced cell death. Production of decoy receptors, ${ }^{73}$ expression of FasL to perform the so-called tumor counterattack ${ }^{74}$ and upregulation of apoptosis inhibitors expression ${ }^{72,75}$ are among the molecular mechanisms involved in this process. We previously reported the frequent decrease of FAS expression in NSCLC. ${ }^{76}$ Importantly, it has been shown than escape from T-cell-mediated immunity 'in vivo' by c-FLIP overexpression was not limited to tumors with high FAS surface expression. ${ }^{52}$ In the light of these data, the low level of E2F1 protein expression in NSCLC with reduced FAS expression could be another way to block FAS-triggered cell death, therefore contributing to the immune escape of tumor cells. In this setting, E2F1 restoration might represent a key step in therapeutic strategies to reconstitute the ability of tumor cells to undergo apoptosis.

\section{Materials and Methods}

\section{Cell lines, expression vectors and transfection}

$\mathrm{H} 358, \mathrm{~A} 549$ and $\mathrm{H} 1299$ human lung carcinoma cell lines as well as Jurkat T cells were cultured in RPMI-1640 medium (GibcoBRL, Life Technologies, Cergy Pontoise, France), supplemented with $10 \%(\mathrm{v} / \mathrm{v})$ heatinactivated fetal calf serum (GibcoBRL), $2 \mathrm{mM} \mathrm{L-glutamine} \mathrm{and} 100 \mathrm{U} / \mathrm{ml}$ penicillin/streptomycin, in $5 \% \mathrm{CO}_{2}$ at $37^{\circ} \mathrm{C}$. Primary murine embryonic fibroblasts (MEFs) derived from wild-type and $\mathrm{E} 2 \mathrm{~F} 1^{-1-}$ mice (kind gift from Dr. Nevins), 293-FasL embryonic kidney cells stably expressing human Fas ligand and HT29 colon cancer cells were maintained in DMEM (GibcoBRL) supplemented with $10 \%(\mathrm{v} / \mathrm{v})$ heat-inactivated fetal calf serum and $2 \mathrm{mM}$ L-glutamine. To ensure exponential growth, cells were resuspended in fresh medium $24 \mathrm{~h}$ before transfection or treatment. Stable inducible E2F1 (wild-type) or E2F1(132) (DNA-binding defective mutant) clones derived from $\mathrm{H} 358$ cells were obtained using a modified tetracyclin-regulated inducible expression system (Tet-On System, Clontech, Ozyme, Saint Quentin en Yvelines, France) as previously described. ${ }^{77}$ E2F1 expression was induced upon $1 \mu \mathrm{g} / \mathrm{ml}$ doxycyclin treatment. Inducible clones stably infected with either VSV-FLIPS expression vector or with a mock vector were provided by 0 . Micheau (INSERM U517, Dijon, France). Transient transfections of A549 and H1299 cells with either control pcDNA3.1/GFP or pcDNA3.1/E2F1 expression vectors were carried out using JetPEI ${ }^{\mathrm{TM}}$ (Polyplus Transfection, Illkirch, France) according to the manufacturer's protocol. In some experiments, geniticin $(800 \mu \mathrm{g} / \mathrm{ml})$ was added to the culture medium $48 \mathrm{~h}$ after transfection and selection was performed during three additional days before analysis.

\section{Tissue samples}

Tissue samples taken at surgical resection of lung tumors were immediately frozen and kept at $-80^{\circ} \mathrm{C}$ until use. They consisted of 12 adenocarcinoma according to the 1999 WHO international histological classification of lung tumors and five matched normal lung samples.

\section{Reagents and antibodies}

Agonistic anti-human Fas monoclonal antibody (clone $\mathrm{CH}-11$ ) and caspase inhibitors z-IETD-fmk, z-DEVD-fmk and Z-LEDH-fmk were obtained from $\mathrm{MBL}$ (MBL, France Biochem, Meudon). For each experiment, caspase inhibitors $(2 \mu \mathrm{M})$ were added to the culture medium $2 \mathrm{~h}$ prior to the addition of doxycyclin $(1 \mu \mathrm{g} / \mathrm{ml})$. Treatment with $\mathrm{CH}-11 \mathrm{mAb}$ $(250 \mathrm{ng} / \mathrm{ml})$ was carried out for $48 \mathrm{~h}$. Soluble Fas ligand was collected from 293-FasL supernatant. Recombinant soluble human FLAG-tagged FasL, Flag-tagged TRAIL and their enhancer were purchased from Alexis (San Diego, CA, USA). Etoposide (VP16), paclitaxel (Taxol ${ }^{\mathrm{TM}}$ ) and cycloheximide were obtained from Sigma (Saint Quentin Fallavier, France). Cycloheximide was used at $10 \mu \mathrm{g} / \mathrm{ml}$ for $12 \mathrm{~h}$.

Monoclonal antibodies used included anti-procaspase-8 (5F7), antiprocaspase-10 (4C1) and anti-Fas (ZB4) (MBL), anti-FADD (1F7), antiFasL (G247-4), anti-procaspase-6 and anti-E2F1(KH95) (Pharmingen BD, San Diego, CA, USA), anti-HSP 70 (Affinity Bioreagents, Golden, CO, USA), anti-actin (Santa Cruz, CA, USA), anti-E2F1(Ab4; Neomarkers, CA, USA), anti-Fas (APO-1 and 3D5) and anti-FLIP (NF6) (Alexis). To block FasL/Fas interaction, anti-Fas (ZB4) was used at concentrations ranging from 2 to $30 \mu \mathrm{g} / \mathrm{ml}$. Polyclonal antibodies used included anti-mouse TRAIL-R2 (R\&D Systems), anti-procaspase-3 and antiactive caspase 3 (Pharmingen BD), anti-procaspase-7 (Cell Signaling, Beverly, MA, USA), anti-procaspase-8 (C-20, Santa Cruz), anti-procaspase-10 (Sigma), antiE2F1 (Santa Cruz Biotechnology) and anti-FLIP (H-202, Santa Cruz Biotechnology).

\section{Cell viability, apoptotic and cytotoxic assays}

Apoptosis was evaluated by scoring the percentage of apoptotic cells on 500 cells after Hoescht 33342 staining. Cytotoxic experiments were performed using the methylene blue colorimetric assay. Briefly, stable inducible clones were seeded at $10^{4}$ cells/well into a 96-wells plate and were cotreated for $96 \mathrm{~h}$ with increasing concentrations of cytotoxic drugs in the presence or absence of doxycyclin. Cells were then fixed in $100 \%$ ethanol, stained with $1 \%$ methylene blue in $0.01 \mathrm{M}$ borate buffer $\mathrm{pH} 8.5$ for $15 \mathrm{~min}$ and optical density was measured at $630 \mathrm{~nm}$ after elution in $0.1 \mathrm{~N}$ $\mathrm{HCl}$. Absorbance values were expressed as a percentage of untreated controls.

Allogenic T-cell cytotoxic assays against tumor target cells were measured in standard $24 \mathrm{~h}^{51} \mathrm{Cr}$-release assays as previously described. ${ }^{78}$ Briefly, $104{ }^{51} \mathrm{Cr}$-labeled target cells were mixed with the effector cells at different $E / T$ ratios $(25 / 1$ to $1 / 1)$ with $E=$ effector cells and $T=$ target cells. The radioactivity in supernatants was counted after $24 \mathrm{~h}$ incubation at $37^{\circ} \mathrm{C}$ in $5 \% \mathrm{CO}$. The percentage of specific lysis was calculated according to the following formula: $\%$ lysis $=100 \times(E R-S R) /(M R-S R)$, where $E R, S R$ and MR represent experimental, spontaneous, and maximum ${ }^{51} \mathrm{Cr}$-release, respectively. All expressed values were derived from average quadruplicate determinations. Effector allogenic $T$ cells were obtained from unidirectional mixed lymphocyte reaction (MLR) as previously described. To induce FasL expression at the cell surface, effector cells were preincubated for $2 \mathrm{~h}$ with a mixture of $5 \mathrm{ng} / \mathrm{ml}$ phorbol 12-myristate 13-acetate (PMA, Sigma) and $1.5 \mu \mathrm{g} / \mathrm{ml} \mathrm{Ca}^{2+}$ ionophore ionomycin (Sigma). Cytotoxic tests were performed on E2F1 stable inducible clones that were pretreated or not with doxycyclin for $72 \mathrm{~h}$, then used as target cells in complete medium supplemented with $15 \%$ human $A$ serum in the presence or absence of $3 \mathrm{mM} \mathrm{EGTA} / 4 \mathrm{mM} \mathrm{Mg}^{2+}$. Jurkat T cells treated in the same conditions were used as positive control target cells.

\section{Western Blot and immunoprecipitation analyses}

For immunoblotting, cells washed three times in PBS or frozen tissue samples were lysed in RIPA buffer $(150 \mathrm{mM} \mathrm{NaCl}, 50 \mathrm{mM}$ Tris $\mathrm{HCl} \mathrm{pH} 8$, 
0.1\%. SDS, 1\% Nonidet P40, 0.5\% Na deoxycholate, $0.1 \mathrm{mM}$ PMSF, $2.5 \mu \mathrm{g} / \mathrm{ml}$ pepstatin, $10 \mu \mathrm{g} / \mathrm{ml}$ aprotinin, $5 \mu \mathrm{g} / \mathrm{ml}$ leupeptin, $0.2 \mathrm{mM}$ $\mathrm{Na}_{3} \mathrm{VO}_{4}$ ) for $30 \mathrm{~min}$ on ice and pelleted. Protein concentration was determined using the Biorad Dc protein assay. Proteins $(40-80 \mu \mathrm{g})$ were then separated in 10-12\% SDS-PAGE gels and electroblotted onto PVDF membranes. Membranes were incubated overnight at $+4^{\circ} \mathrm{C}$ with primary antibodies and proteins were detected using horseradish peroxidaseconjugated goat anti-mouse or anti-rabbit antibodies (Jackson Immunoresearch Laboratories, West Grove, PA, USA). After washing, the blots were revealed using the ECL chemiluminescence method (Amersham, Les Ulis, France), according to the manufacturer's protocol.

For DISC immunoprecipitation, $50 \times 10^{6}$ cells were lysed in lysis buffer (20 mM Tris- $\mathrm{HCl} \mathrm{pH} \mathrm{7.4,} 150 \mathrm{mM} \mathrm{NaCl}, 1 \% \mathrm{NP} 40,2 \mathrm{mM}$ sodium vanadate, $1 \mathrm{mM}$ AEBSF and $10 \mu \mathrm{g} / \mathrm{ml}$ aprotinin) for $15 \mathrm{~min}$ on ice and the supernatants were collected by centrifugation at 12000 r.p.m. for $15 \mathrm{~min}$. Supernatants were precleared with Sepharose 6B (Sigma) for $1 \mathrm{~h}$ at $+4^{\circ} \mathrm{C}$ and immunoprecipitation of the FAS receptor was further performed overnight at $+4^{\circ} \mathrm{C}$ on precleared lysates in presence of protein $\mathrm{G}$ sepharose and $2 \mu \mathrm{g}$ of FLAG-tagged-Fc-FasL (provided by Olivier Micheau). Protein $G$ sepharose beads were spun down, washed four times with lysis buffer, resuspended in SDS gel sample buffer and boiled at $95^{\circ} \mathrm{C}$ for $4 \mathrm{~min}$. Immunoprecipitates were separated in $12 \% \mathrm{SDS} /$ PAGE gel and immunoblotted with either anti-Fas (C-20, Santa-Cruz), anti-FADD (1F7, mouse IgG1, Immunotech), anti-caspase-8 (5F7, mouse IgG2b, Immunotech) or anti-caspase-10 (4C1, mouse IgG1, MBL) antibodies. Secondary antibodies used were anti-mouse HRP-lgG1 (Southern Biotechnology) to detect FADD and caspase-10, anti-mouse HRP-IgG2b (Southern Biotechnology) to detect caspase-8 or anti-rabbit HRP to detect Fas (C-20).

\section{Indirect immunofluorescence and Fas clustering studies}

Transfected $\mathrm{A} 549$ and $\mathrm{H} 1299$ cells were fixed in $-20^{\circ} \mathrm{C}$ acetone for $5 \mathrm{~min}$. After extended washes, nonspecific binding sites were saturated for $45 \mathrm{~min}$ at RT in 2\% BSA, 10\% normal goat serum, $1 \times \mathrm{PBS}$ and incubation with anti-E2F1 mAb (Ab4, 1/2000) was carried out for $2 \mathrm{~h}$ at RT in PBS, $2 \%$ BSA. After three PBS washes, Alexa TM ${ }^{568}$ goat anti-mouse $\operatorname{lgG}(\mathrm{H}+\mathrm{L})$ conjugate $(2 \mathrm{mg} / \mathrm{ml}, 1 / 1000$, Interchim Montluçon, France) was added and cells were further incubated for $30 \mathrm{~min}$ in dark at $37^{\circ} \mathrm{C}$. Cells were then washed three times in PBS, counterstained with Hoescht 33342 and observed using an Olympus microscope. For Fas clustering analysis, $10^{4} \mathrm{H} 358$ stable inducible cells were seeded onto immunofluorescence slides and cultured in the presence or absence of doxycyclin for 6 days. Cells were then fixed in 3\% paraformaldehyde/PBS for $10 \mathrm{~min}$, washed twice with PBS for $10 \mathrm{~min}$, preincubated with $1 \% \mathrm{BSA}$ for $15 \mathrm{~min}$, and incubated for $2 \mathrm{~h}$ at RT with anti-Fas $\mathrm{mAb}(\mathrm{Zb} 4)$ in $1 \%$ BSA, PBS. Samples were washed twice in PBS and stained using the Alexa TM ${ }^{568}$ goat anti-mouse $\lg \mathrm{G}(\mathrm{H}+\mathrm{L})$ conjugate. Cells were visualized using a confocal laser (Spectra Physics) microscope (Zeiss, LSM510). For all experiments, a nonrelevant isotype matching antibody was used as a negative control (data not shown). HT29 colon cancer cells treated with $25 \mathrm{ng} / \mathrm{ml}$ soluble FasL (Alexis Biochemical) were used as a positive control of FAS clustering.

\section{Transfection of siRNA oligonucleotides}

The siRNA oligonucleotides were synthesized by Eurogentec and resuspended according to the manufactuter's protocol (Eurogentec,
Seraing, Belgium). The sequence designed to target specifically human flip short mRNA was as follow: 5'-CACCCUAUGCCCAUUGUCCTT-3'. The sequence designed to target specifically the mouse flip short mRNA was as follow: 5-CCAGUGUAUGGAGUACCAGTT- $3^{\prime}$ The scrambled siRNA oligonucleotides used as control were 5'-ACAUACGCUUU CGCCCCUTT- $3^{\prime}$ for human cells and 5'-CCAAUGGGUUGACAGUC AGTT-3' for mouse cells. For siRNA transfection, stable E2F1-inducibles clones or E2F1 ${ }^{-1-}$ MEFs were seeded onto a six-well plate at $5 \times 10^{5}$ or $2 \times 10^{5}$ cells/well, respectively. On the next day, the cells were transfected with siRNA oligonucleotides duplex using Oligofectamine ${ }^{\mathrm{TM}}$ (Invitrogen, Cergy Pontoise, France) according to the manufacturer's instructions. Briefly, $10 \mu \mathrm{l}$ of siRNA duplex (at $20 \mu \mathrm{M}$ ) were mixed with $185 \mu$ l of serumfree RPMI/DMEM medium. Oligofectamine ${ }^{\mathrm{TM}}(3 \mu \mathrm{l})$ was added to $12 \mu \mathrm{l}$ of RPMI/DMEM serum-free medium, vortexed, incubated at RT for 10 min and gently mixed with the siRNA duplex solution. Mixture was incubated for $20 \mathrm{~min}$ at RT and added to each well. At $4 \mathrm{~h}$ after transfection, $10 \%$ fetal calf serum was added. Doxycyclin was added or not in culture medium $24 \mathrm{~h}$ after transfection and cells were cultured additionally for $48 \mathrm{~h}$ before analysis. In some experiments, stable inducible clones were transfected for $43 \mathrm{~h}$, then treated during 5 additional hours with either $500 \mathrm{ng} / \mathrm{ml}$ antiFas agonistic $\mathrm{CH} 11 \mathrm{mAb}$ or $100 \mathrm{ng} / \mathrm{ml}$ TRAIL before analysis. E2F1 ${ }^{-/-}$ MEFs were transfected for $50 \mathrm{~h}$ with $c$-flip or mismatch siRNA, then treated for 20 additional hours with either $25 \mathrm{ng} / \mathrm{ml}$ FasL in the presence of $1 \mu \mathrm{g} / \mathrm{ml}$ enhancer or $40 \mathrm{ng} / \mathrm{ml}$ KillerTRAIL ${ }^{\mathrm{TM}}$ (Alexis Biochemical).

\section{Reverse transcription-polymerase chain reaction (RT-PCR)}

Total cellular RNAs were isolated using Trizol reagent (Invitrogen). In all, $1 \mu \mathrm{g}$ of total RNA was subjected to RT in a $20 \mu$ reaction volume using oligo(dT) primer and M-MLV reverse transcriptase (Invitrogen) according to the manufacturer's protocol. RT reaction $(3 \mu \mathrm{l})$ was then amplified by PCR for 30 cycles using the following conditions: $94^{\circ} \mathrm{C}$ for $30 \mathrm{~s} ; 58^{\circ} \mathrm{C}$ for $1 \mathrm{~min}$ and $72^{\circ} \mathrm{C}$ for $2 \mathrm{~min}$. The primers used were: flip short forward (sense): $5^{\prime}$-CGAGGCAAGATAAGCAAGGA-3'; flip short reverse (antisense): $5^{\prime}$-CACATGGAACAATTTCCAAGAA-3'; flip long forward (sense): 5'-CTTGGCCAATTTGCCTGTAT-3'; flip long reverse (antisense): $5^{\prime}$ GGCAGAAACTCTGCTGTTCC-3'. Amplification of a fragment of the CDNA of G3PDH (Invitrogen) was performed in the same PCR reaction as internal control. PCR products were run on a $2 \%$ agarose gel and visualized by ethidium bromide staining.

\section{Statistical analyses}

Quantitative experiments were analysed by the use of Student's paired $t$ test $\left({ }^{\star} P<0.05 ; .{ }^{\star \star} P<0.01 ;{ }^{\star \star \star} P<0.001\right)$.

\section{Acknowledgements}

We thank Dr K. Helin and Dr J. Nevins for providing plasmids and cells. We also thank Dr Alicia Lajmanovitch (INSERM, EMI353) for helpful discussions. This work was supported by a grant to E.B. from La Ligue Nationale Contre le Cancer as an 'équipe labellisée' and by the Region Rhône Alpes (Thématique prioritaire cancer and Canceropole 2003: Oncocell, Epimed and INACancer). C.S. was supported by a 'poste accueil' INSERM. We thank Celine Lampreia and Pascal Perron for technical assistance. 


\section{References}

1. DeGregori $J(2002)$ The genetics of the E2F family of transcription factors: shared functions and unique roles. Biochim. Biophys. Acta 1602: 131-150

2. Dyson N (1998) The regulation of E2F by pRB-family proteins. Genes Dev. 12 : 2245-2262

3. Di Stefano L, Jensen MR and Helin K (2003) E2F7, a novel E2F featuring DP. independent repression of a subset of E2F-regulated genes. EMBO J. 22 6289-6298

4. Harbour JW and Dean DC (2000) The Rb/E2F pathway: expanding roles and emerging paradigms. Genes Dev. 14: 2393-2409

5. DeGregori J, Leone G, Miron A, Jakoi L and Nevins JR (1997) Distinct roles for E2F proteins in cell growth control and apoptosis. Proc. Natl. Acad. Sci. USA 94: 7245-7250

6. Johnson DG, Schwarz JK, Cress WD and Nevins JR (1993) Expression of transcription factor E2F1 induces quiescent cells to enter $\mathrm{S}$ phase. Nature 365 : 349-352

7. Qin XQ, Livingston DM, Kaelin Jr WG and Adams PD (1994) Deregulated transcription factor E2F-1 expression leads to S-phase entry and p53-mediated apoptosis. Proc. Natl. Acad. Sci. USA 91: 10918-10922

8. Wu X and Levine AJ (1994) p53 and E2F-1 cooperate to mediate apoptosis. Proc. Natl. Acad. Sci. USA 91: 3602-3606

9. Kowalik TF, DeGregori J, Leone G, Jakoi L and Nevins JR (1998) E2F1-specific induction of apoptosis and p53 accumulation, which is blocked by Mdm2. Cell Growth Differ. 9: 113-118

10. Field SJ, Tsai FY, Kuo F, Zubiaga AM, Kaelin Jr WG, Livingston DM, Orkin SH and Greenberg ME (1996) E2F-1 functions in mice to promote apoptosis and suppress proliferation. Cell 85: $549-561$

11. Garcia I, Murga M, Vicario A, Field SJ and Zubiaga AM (2000) A role for E2F1 in the induction of apoptosis during thymic negative selection. Cell Growth Differ. 11: 91-98

12. Yamasaki L, Jacks T, Bronson R, Goillot E, Harlow E and Dyson NJ (1996) Tumor induction and tissue atrophy in mice lacking E2F-1. Cell 85: 537-548

13. Hiebert SW, Packham G, Strom DK, Haffner R, Oren M, Zambetti G and Cleveland JL (1995) E2F-1:DP-1 induces p53 and overrides survival factors to trigger apoptosis. Mol. Cell. Biol. 15: 6864-6874

14. Hsieh JK, Fredersdorf S, Kouzarides T, Martin K and Lu X (1997) E2F1. induced apoptosis requires DNA binding but not transactivation and is inhibited by the retinoblastoma protein through direct interaction. Genes Dev. 11: 1840-1852

15. Ginsberg D (2002) E2F1 pathways to apoptosis. FEBS Lett. 529: 122-125

16. Cao Q, Xia Y, Azadniv M and Crispe IN (2004) The E2F-1 transcription factor promotes caspase-8 and bid expression, and enhances Fas signaling in T cells. J. Immunol. 173: 1111-1117

17. Hou ST, Xie X, Baggley A, Park DS, Chen G and Walker T (2002) Activation of the Rb/E2F1 pathway by the nonproliferative p38 MAPK during Fas (AP01/ CD95)-mediated neuronal apoptosis. J. Biol. Chem. 277: 48764-48770

18. Itoh N, Yonehara S, Ishii A, Yonehara M, Mizushima S, Sameshima M, Hase A Seto $Y$ and Nagata $S$ (1991) The polypeptide encoded by the cDNA for human cell surface antigen Fas can mediate apoptosis. Cell 66: 233-243

19. Boldin MP, Varfolomeev EE, Pancer Z, Mett IL, Camonis JH and Wallach D (1995) A novel protein that interacts with the death domain of Fas/APO1 contains a sequence motif related to the death domain. J. Biol. Chem. 270: 7795-7808

20. Chinnaiyan AM, O'Rourke K, Tewari M and Dixit VM (1995) FADD, a nove death domain-containing protein, interacts with the death domain of Fas and initiates apoptosis. Cell 81: 505-512

21. Boldin MP, Goncharov TM, Goltsev YV and Wallach D (1996) Involvement of $\mathrm{MACH}$, a novel MORT1/FADD-interacting protease, in Fas/APO-1- and TNF receptor-induced cell death. Cell 85: 803-815

22. Srinivasula SM, Ahmad M, Fernandes-Alnemri T, Litwack $G$ and Alnemri ES (1996) Molecular ordering of the Fas-apoptotic pathway: the Fas/APO-1 protease Mch5 is a CrmA-inhibitable protease that activates multiple Ced-3/ ICE-like cysteine proteases. Proc. Natl. Acad. Sci. USA 93: 14486-14491

23. Muzio M, Chinnaiyan AM, Kischkel FC, O'Rourke K, Shevchenko A, Ni J, Scaffidi C, Bretz JD, Zhang M, Gentz R, Mann M, Krammer PH, Peter ME and Dixit VM (1996) FLICE, a novel FADD-homologous ICE/CED-3-like protease, is recruited to the CD95 (Fas/APO-1) death-inducing signaling complex. Cell 85 $817-827$
24. Kischkel FC, Hellbardt S, Behrmann I, Germer M, Pawlita M, Krammer PH and Peter ME (1995) Cytotoxicity-dependent APO-1 (Fas/CD95)-associated proteins form a death-inducing signaling complex (DISC) with the receptor. EMBO J. 14: 5579-5588

25. Medema JP, Scaffidi C, Kischkel FC, Shevchenko A, Mann M, Krammer PH and Peter ME (1997) FLICE is activated by association with the CD95 deathinducing signaling complex (DISC). EMBO J. 16: 2794-2804

26. Hirata H, Takahashi A, Kobayashi S, Yonehara S, Sawai H, Okazaki T, Yamamoto K and Sasada M (1998) Caspases are activated in a branched protease cascade and control distinct downstream processes in Fas-induced apoptosis. J. Exp. Med. 187: 587-600

27. Scaffidi C, Fulda S, Srinivasan A, Friesen C, Li F, Tomaselli KJ, Debatin KM, Krammer PH and Peter ME (1998) Two CD95 (APO-1/Fas) signaling pathways. EMBO J. 17: 1675-1687

28. Goltsev YV, Kovalenko AV, Arnold E, Varfolomeev EE, Brodianskii VM and Wallach D (1997) CASH, a novel caspase homologue with death effector domains. J. Biol. Chem. 272: 19641-19644

29. Han DK, Chaudhary PM, Wright ME, Friedman C, Trask BJ, Riedel RT, Baskin DG, Schwartz SM and Hood L (1997) MRIT, a novel death-effector domaincontaining protein, interacts with caspases and BcIXL and initiates cell death. Proc. Natl. Acad. Sci. USA 94: 11333-11338

30. Hu S, Vincenz C, Ni J, Gentz R and Dixit VM (1997) I-FLICE, a novel inhibitor of tumor necrosis factor receptor-1- and CD-95-induced apoptosis. J. Biol. Chem. 272: 17255-17257

31. Inohara N, Koseki T, Hu Y, Chen S and Nunez G (1997) CLARP, a death effector domain-containing protein interacts with caspase-8 and regulates apoptosis. Proc. Natl. Acad. Sci. USA 94: 10717-10722

32. Irmler M, Thome M, Hahne M, Schneider P, Hofmann K, Steiner V, Bodmer JL, Schroter M, Burns K, Mattmann C, Rimoldi D, French LE and Tschopp J (1997) Inhibition of death receptor signals by cellular FLIP. Nature 388: 190-195

33. Shu HB, Halpin DR and Goeddel DV (1997) Casper is a FADD- and caspaserelated inducer of apoptosis. Immunity 6: 751-763

34. Srinivasula SM, Ahmad M, Ottilie S, Bullrich F, Banks S, Wang Y, FernandesAlnemri T, Croce CM, Litwack G, Tomaselli KJ, Armstrong RC and Alnemri ES (1997) FLAME-1, a novel FADD-like anti-apoptotic molecule that regulates Fas/ TNFR1-induced apoptosis. J. Biol. Chem. 272: 18542-18545

35. Krueger A, Schmitz I, Baumann S, Krammer PH and Kirchhoff S (2001) Cellular FLICE-inhibitory protein splice variants inhibit different steps of caspase-8 activation at the CD95 death-inducing signaling complex. J. Biol. Chem. 276: 20633-20640

36. Chang DW, Xing Z, Pan Y, Algeciras-Schimnich A, Barnhart BC, Yaish-Ohad $S$, Peter ME and Yang X (2002) c-FLIP(L) is a dual function regulator for caspase-8 activation and CD95-mediated apoptosis. EMBO J. 21: 3704-3714

37. Micheau O, Thome M, Schneider P, Holler N, Tschopp J, Nicholson DW, Briand C and Grutter MG (2002) The long form of FLIP is an activator of caspase-8 at the Fas death-inducing signaling complex. J. Biol. Chem. 277: 45162-45171

38. Boatright KM, Deis C, Denault JB, Sutherlin DP and Salvesen GS (2004) Activation of caspases-8 and -10 by FLIP(L). Biochem. J. 382: 651-657

39. Mathas S, Lietz A, Anagnostopoulos I, Hummel F, Wiesner B, Janz M, Jundt F, Hirsch B, Johrens-Leder K, Vornlocher HP, Bommert K, Stein H and Dorken B (2004) c-FLIP mediates resistance of Hodgkin/Reed-Sternberg cells to death receptor-induced apoptosis. J. Exp. Med. 199: 1041-1052

40. Eymin B, Gazzeri S, Brambilla C and Brambilla E (2001) Distinct pattern of E2F1 expression in human lung tumours: E2F1 is upregulated in small cell lung carcinoma. Oncogene 20: 1678-1687

41. Phillips AC, Bates S, Ryan KM, Helin K and Vousden KH (1997) Induction of DNA synthesis and apoptosis are separable functions of E2F-1. Genes Dev. 11: 1853-1863

42. Nahle Z, Polakoff J, Davuluri RV, McCurrach ME, Jacobson MD, Narita M, Zhang MQ, Lazebnik Y, Bar-Sagi D and Lowe SW (2002) Direct coupling of the cell cycle and cell death machinery by E2F. Nat. Cell. Biol. 4: 859-864

43. Fulda S, Friesen C, Los M, Scaffidi C, Mier W, Benedict M, Nunez G, Krammer $\mathrm{PH}$, Peter ME and Debatin KM (1997) Betulinic acid triggers CD95 (APO-1/ Fas)- and p53-independent apoptosis via activation of caspases in neuroectodermal tumors. Cancer Res. 57: 4956-4964

44. Aragane Y, Kulms D, Metze D, Wilkes G, Poppelmann B, Luger TA and Schwarz T (1998) Ultraviolet light induces apoptosis via direct activation of CD95 (Fas/APO-1) independently of its ligand CD95L. J. Cell Biol. 140: 171-182 
45. Boesen-de Cock JG, de Vries E, Williams GT and Borst J (1998) The anticancer drug etoposide can induce caspase-8 processing and apoptosis in the absence of CD95 receptor-ligand interaction. Apoptosis 3: 17-25

46. Micheau O, Solary E, Hammann A and Dimanche-Boitrel MT (1999) Fas ligand-independent, FADD-mediated activation of the Fas death pathway by anticancer drugs. J. Biol. Chem. 274: 7987-7992

47. Algeciras-Schimnich A, Shen L, Barnhart BC, Murmann AE, Burkhardt JK and Peter ME (2002) Molecular ordering of the initial signaling events of CD95. Mol. Cell. Biol. 22: 207-220

48. Kagi D, Vignaux F, Ledermann B, Burki K, Depraetere V, Nagata S, Hengartner $H$ and Golstein P (1994) Fas and perforin pathways as major mechanisms of $T$ cell-mediated cytotoxicity. Science 265: 528-530

49. Lowin B, Hahne M, Mattmann C and Tschopp J (1994) Cytolytic T-cell cytotoxicity is mediated through perforin and Fas lytic pathways. Nature 370 : 650-652

50. Mami-Chouaib F, Echchakir H, Dorothee G, Vergnon I and Chouaib S (2002) Antitumor cytotoxic T-lymphocyte response in human lung carcinoma: identification of a tumor-associated antigen. Immunol. Rev. 188: 114-121

51. Djerbi M, Screpanti V, Catrina Al, Bogen B, Biberfeld P and Grandien A (1999) The inhibitor of death receptor signaling, FLICE-inhibitory protein defines a new class of tumor progression factors. J. Exp. Med. 190: 1025-1032

52. Medema JP, de Jong J, van Hall T, Melief CJ and Offringa R (1999) Immune escape of tumors in vivo by expression of cellular FLICE-inhibitory protein. J. Exp. Med. 190: 1033-1038

53. Irwin M, Marin MC, Phillips AC, Seelan RS, Smith DI, Liu W, Flores ER, Tsai KY, Jacks T, Vousden KH and Kaelin Jr WG (2000) Role for the p53 homologue p73 in E2F-1-induced apoptosis. Nature 407: 645-648

54. Stiewe T and Putzer BM (2000) Role of the p53-homologue p73 in E2F1induced apoptosis. Nat. Genet. 26: 464-469

55. Moroni MC, Hickman ES, Denchi EL, Caprara G, Colli E, Cecconi F, Muller H and Helin K (2001) Apaf-1 is a transcriptional target for E2F and p53. Nat Cell. Biol. 3: 552-558

56. Furukawa $Y$, Nishimura N, Satoh M, Endo H, Iwase S, Yamada H, Matsuda M, Kano $Y$ and Nakamura M (2002) Apaf-1 is a mediator of E2F-1-induced apoptosis. J. Biol. Chem. 277: 39760-39768

57. Phillips AC, Ernst MK, Bates S, Rice NR and Vousden KH (1999) E2F-1 potentiates cell death by blocking antiapoptotic signaling pathways. Mol. Cell 4: $771-781$

58. Wang S, Nath N, Minden A and Chellappan S (1999) Regulation of Rb and E2F by signal transduction cascades: divergent effects of JNK1 and p38 kinases. EMBO J. 18: 1559-1570

59. Bi B, Littlewood NK and Crispe IN (2001) Cleavage of E2F-1-regulating proteins and activation of E2F-1 during CD95-induced death of thymocytes. Immunology 104: 37-42

60. Tschopp J, Irmler M and Thome M (1998) Inhibition of fas death signals by FLIPs. Curr. Opin. Immunol. 10: 552-558

61. Jiang Y, Rom WN, Yie TA, Chi CX and Tchou-Wong KM (1999) Induction of tumor suppression and glandular differentiation of A549 lung carcinoma cells by dominant-negative IGF-I receptor. Oncogene 18: 6071-6077

62. Fulda S, Meyer E and Debatin KM (2000) Metabolic inhibitors sensitize for CD95 (APO-1/Fas)-induced apoptosis by down-regulating Fas-associated death domain-like interleukin 1-converting enzyme inhibitory protein expression. Cancer Res. 60: 3947-3956
63. Thome M, Schneider P, Hofmann K, Fickenscher H, Meinl E, Neipel F, Mattmann C, Burns K, Bodmer JL, Schroter M, Scaffidi C, Krammer PH, Peter ME and Tschopp J (1997) Viral FLICE-inhibitory proteins (FLIPs) prevent apoptosis induced by death receptors. Nature 386: $517-521$

64. Bin L, Li X, Xu LG and Shu HB (2002) The short splice form of Casper/c-FLIP is a major cellular inhibitor of TRAIL-induced apoptosis. FEBS Lett. 510: 37-40

65. Kirchhoff S, Muller WW, Krueger A, Schmitz I and Krammer PH (2000) TCR-mediated up-regulation of c-FLIPshort correlates with resistance toward CD95-mediated apoptosis by blocking death-inducing signaling complex activity. J. Immunol. 165: 6293-6300

66. Lieman JH, Worley LA and Harbour JW (2005) Loss of Rb-E2F repression results in caspase-8 mediated apoptosis through inactivation of focal adhesion kinase. J. Biol. Chem. 280: 10484-10490

67. Fukazawa T, Fujiwara T, Uno F, Teraishi F, Kadowaki Y, Itoshima T, Takata $Y$, Kagawa S, Roth JA, Tschopp J and Tanaka N (2001) Accelerated degradation of cellular FLIP protein through the ubiquitin-proteasome pathway in p53mediated apoptosis of human cancer cells. Oncogene 20: 5225-5231

68. Kim Y, Suh N, Sporn M and Reed JC (2002) An inducible pathway for degradation of FLIP protein sensitizes tumor cells to TRAIL-induced apoptosis. J. Biol. Chem. 277: 22320-22329

69. Stanelle J, Stiewe T, Theseling CC, Peter M and Putzer BM (2002) Gene expression changes in response to E2F1 activation. Nucleic Acids Res. 30: 1859-1867

70. Burns TF and El-Deiry WS (2001) Identification of inhibitors of TRAIL-induced death (ITIDs) in the TRAIL-sensitive colon carcinoma cell line SW480 using a genetic approach. J. Biol. Chem. 276: 37879-37886

71. Schmitz I, Weyd H, Krueger A, Baumann S, Fas SC, Krammer PH and Kirchhoff S (2004) Resistance of short term activated T cells to CD95-mediated apoptosis correlates with de novo protein synthesis of c-FLIP(short). J. Immunol. 172: 2194-2200

72. French LE and Tschopp J (2002) Defective death receptor signaling as a cause of tumor immune escape. Semin. Cancer Biol. 12: 51-55

73. Roth W, Isenmann S, Nakamura M, Platten M, Wick W, Kleihues P, Bahr M, Ohgaki $\mathrm{H}$, Ashkenazi A and Weller M (2001) Soluble decoy receptor 3 is expressed by malignant gliomas and suppresses CD95 ligand-induced apoptosis and chemotaxis. Cancer Res. 61: 2759-2765

74. Hahne M, Rimoldi D, Schroter M, Romero P, Schreier M, French LE, Schneider P, Bornand T, Fontana A, Lienard D, Cerottini J and Tschopp J (1996) Melanoma cell expression of Fas(Apo-1/CD95) ligand: implications for tumor immune escape. Science 274: 1363-1366

75. Mitsiades CS, Mitsiades N, Poulaki V, Schlossman R, Akiyama M, Chauhan D, Hideshima T, Treon SP, Munshi NC, Richardson PG and Anderson KC (2002) Activation of NF-kappaB and upregulation of intracellular anti-apoptotic proteins via the IGF-1/Akt signaling in human multiple myeloma cells: therapeutic implications. Oncogene 21: 5673-5683

76. Viard-Leveugle I, Veyrenc S, French LE, Brambilla C and Brambilla E (2003) Frequent loss of Fas expression and function in human lung tumours with overexpression of FasL in small cell lung carcinoma. J. Pathol. 201: 268-277

77. Eymin B, Leduc C, Coll JL, Brambilla E and Gazzeri S (2003) p14ARF induces $\mathrm{G} 2$ arrest and apoptosis independently of p53 leading to regression of tumours established in nude mice. Oncogene 22: 1822-1835

78. Plumas J, Jacob MC, Chaperot L, Molens JP, Sotto JJ and Bensa JC (1998) Tumor B cells from non-Hodgkin's lymphoma are resistant to CD95 (Fas/Apo1)-mediated apoptosis. Blood 91: 2875-2885 